\title{
NIQAB, PROTEST MOVEMENT, AND THE SALAFIZATION OF INDONESIAN ISLAM
}

\author{
Maghfur Ahmad \\ Institut Agama Islam Negeri (IAIN) Pekalongan \\ maghfur@iainpekalongan.ac.id \\ Siti Mumun Muniroh \\ Institut Agama Islam Negeri (IAIN) Pekalongan \\ sitimuniroh1782@gmail.com \\ Shinta Nurani \\ Institut Agama Islam Negeri (IAIN) Pekalongan \\ shinta.nurani@iainpekalongan.ac.id
}

\begin{abstract}
This study aims to reveal the niqab as a protest movement and an instrument of regeneration (salafization) for Salafi Muslim women in Indonesia. The niqab has been one of the important symbols in the Salafi Islamic movement and has been the main dress for Salafi Muslim women. This study is of importance since the existing niqab studies are more related to religious identity, culture, motivation, stigma, and stereotypes. Data in this phenomenological research were obtained through interviews, observations, and documentation involving the niqab-wearing women from Salafi Islam activists at Majlis Ta'lim Al-Izzah of Pekalongan and Pondok Pesantren SJR AlSalafy of Yogyakarta. The data were then analyzed with the
\end{abstract}


Moustakas' model. This study has shown that the niqab in the internal circle of Salafi Islam has a plural meaning. Among Salafi Muslims, it not only functions as a cultural identity or a symbol of piety in religion but also holds the spirit of protest, resistance, struggle, and an instrument of $d a^{\prime} w a h$ to expand the influence of Salafi ideology. That is, the niqab has become a symbol of resistance to both the hegemony of religiosity and the established dressing culture for Indonesian Muslim women. It is also a symbol of the struggle towards the kaffah Islam and an essential instrument for the regeneration of Salafi Islam. Overall, the niqab phenomenon in Indonesia indicates that the salafization in Indonesian Islam has been running in a structured, massive, and sustainable way.

Keywords: Islamism, Kaffah Islam, Niqab, Salafism, and Resistance Movement.

\section{A. Introduction}

The study of the niqab, Salafism, and the Salafi Muslim women's protest movement has become an engaging issue along with the increasing interest in wearing the niqab. The niqab as the main subject of this article is commonly understood as the garment worn by some Muslim women to cover its wearer's face, leaving only eyes visible (Razack, 2018). Ramadhini's study informed that there is an increasing trend in using the niqab in various communities and levels of Indonesian Muslim society (Ramadhini, 2017). The rise of Muslim women wearing niqab is often seen as the dynamic of the community's religious behavior. However, the stigma against them is getting worse as the spread of violence and religious radicalism. Those wearing the niqab are likely accused of being part of an exclusive and radical groups, even part of the terrorism movement (Rahman \& Syafiq, 
2017; Scheid \& Wright, 2017; Zempi, 2019). The ban on the niqab, as a religious or cultural symbol, in public spaces is also increasingly widespread in European countries such as France (Zempi, 2019) and in countries with a majority Muslim population (Haryanto, 2015). Further, the study of the niqab left academic debates. Nasir, for example, revealed that the niqab-related issues have become a controversial topic and resulted in heated debates among feminists, Islamists, and liberal-secularist groups (Nasir, 2004).

This study intends to explore and analyze the use of the niqab by Muslim women as a protest movement, political resistance, and regeneration instrument in expanding the influence of Salafi Islam in Indonesia (also known as the salafization). Studies on the niqab have been focused more on the context of religious, cultural, and social identity. The results of the previous studies, for example, find the niqab as a form of oppression, marginalization, exclusion of women (Jailani, 2016; Jardim \& Vorster, 2003), and a means of patriarchal control against women (Mernissi, 1999). Another study reveals that the niqab symbolizes the self-image of a community whose meaning depends on the cultural and contextual situation (Hochel, 2013).

Unlike those studies, this current study proposes different perspectives. The study does not stop at the conclusion that wearing the niqab is a conscious choice for Muslim women in the name of comfort, fashion, and modesty following religious reasoning (Wagner, Sen, Permanadeli, \& Howarth, 2012); instead, this study shows that the wearing of the niqab by Salafist Muslim women is not only intended as a religious expression but a form of protest, resistance, and strategy to expand the influence of Salafi Islam. Besides, unlike Tarik Kulenovi's study that sees the niqab as a form 
of resistance to the mainstream of modernity (Kulenović, 2006), this study provides evidence and arguments that the niqab-wearing is a form of resistance to local values, traditional religious practices, non-sharia-based clothing, and market domination by investors. Thus, this study differs from previous findings that the niqab is an ideological doctrine that deals with democratic systems and nationalism (Dzuhayatin, 2020); identity politics (Pirol \& Aswan, 2021); political identity (Saputra, Tanjung, \& Augus, 2021); the niqab policy damages human rights and group welfare (Syed, 2021); and the ban on the niqab is a form of social injustice (CohenAlmagor, 2021).

This study employed a qualitative approach and a phenomenological analysis. Data of the study were obtained through interviews, observation, and documentation. The data were analyzed with the Moustakas' model (Moustakas, 1994), including epoche, phenomenological reduction, imaginative variation, and synthesis of meanings. The subjects of this study involved the niqab-wearing women from Salafi Islam activists at Majlis Ta'lim Al-Izzah of Pekalongan and Pondok Pesantren SJR Al-Salafy of Yogyakarta. The interviews and observations were conducted from June to September 2019. Thus, this study is designed to analyze the niqab in socio-political construction, contestation, and its dynamics within the Salafi community, both as a symbol of protest and resistance movement and as an instrument for the regeneration of Salafi Islam in Indonesia.

\section{B. Salafi Islam and the Socio-political Resistance Movement}

The niqab and the Salafi Islam are two inseparable things; both have a symbiotic and symbolic relationship. 
McLarney, for instance, maintained that the niqab is an important identity in Salafi Islam (McLarney, 2009). In the Salafism movement, he said, the niqab has a very decisive position and role in expanding the influence of the Salafi Islamic doctrines. Meanwhile, a study conducted by Karim (Karim, 2016) showed that the construction of meanings and symbols concerning the niqab is very urgent when one discusses Islamism -of which Salafism is one of its concernsin Indonesia. Salafi Muslims, through Islamic politics, believe that Islam must be symbolically manifested in state politics (Karim, 2016).

Salafism is an Islamic thought and movement that refers to the system of thinking of the Salafi scholars. The term "salaf" literally means the past and earlier period. In the context of periodization, the salaf generation refers to the first generation of Muslims that include sahabah (the Prophet's companions), tabi'in (the followers), and tabi' at-tabi'in (followers of the followers). This generation is considered the best Muslim generation in Islamic history and has a place of honor and prestige. As a movement and thought, Salafism has its own system of thinking and ijtihad (independent reasoning to find a solution to a legal question) called Manhaj Salaf to refer to the methods and patterns of $d a^{\prime}$ wah of the previous generations of Islam. In this sense, the Salafis consider that Islamic teachings must refer to and follow the teachings during the Prophet, companions, tabi'in, and tabi' at-tabi'in. Ahmad bin Hambal, who lived in 780-855 CE/ 164-241 AH, is considered the last scholar of the Salafi generation (Esposito, 2002: 104).

Furthermore, Salafiyah has been interchangeably used with 'reform' (ishlah) and 'renewal' (tajdid). Indeed, both reform and renewal are the main concepts in the structure 
of the Islamic movement. Prominent figures in the Salafi movement include Muhammad Abduh (1849-1905 CE) and Muhammad Rasyid Rida (1865-1935 CE), as they promote the issue of renewal and purification spirit. On that basis, Salafis are often associated with followers who hold to the principles of the Salafi generation. Notable scholar of the classical Salafi, Ahmad bin Hambal instilled important principles of the Salafi doctrine. First, Muslims must prioritize sacred texts over reason; the texts must be explained under the provisions of Arabic language, hadith, and the understanding of the Salafi al-Shalih (the pious Predecessors). Second, Muslims must reject argumentative logic carried out by the scholars of Kalam. Third, Muslims must make the Quran, sunnah, and ijma (consensus) of the Salafi al-Shalih the primary sources of Islamic teachings.

Another prominent figure of Salafi movement is Muhammad bin Abdul Wahhab. This figure is widely known as the originator of the Wahhabi movement and has initiated the basic principles of Salafism, namely (a) Islamic knowledge (al-ilm), (b) purifying monotheism and eradicating polytheism (al-tauhid), (c) reviving the sunnah and eradicating bid'ah or heresy (al-sunnah), (d) purifying the treasures of Islamic sciences (al-tasfiyah), (e) spreading straight Islamic teachings (al-da'wah), (f) inviting goodness and preventing evil (amar ma'ruf nahi munkar), (g) enforcing God's law in the state and society (tathbiq al-syari'ah), (h) opening the doors of ijtihad to respond to contemporary problems of the ummah (alijtihad), (i) defending Allah's religion and Muslim countries with the power of arms (jihad fi sabilillah), and (j) purifying the soul (al-tazkiyah) (Chozin, 2013).

The Salafi Islam in Indonesia has various versions; it is not a monolithic community and is respectively connected 
with countries in the Middle East, such as Yemen and Saudi Arabia. This fact helps illustrate a tendency towards different ideologies. The Salafi movement in Indonesia in the 1990s, for example, experienced a conflict or split. There were the reformist group (al-Salafiyyah al-Ilmiyyah) and the jihadist group (al-Salafiyyah al-Jihadiyyah). Such a polarization among Salafi Muslims can be seen from (a) the conflict between Ja'far Umar Thalib and Yusuf Baisa, and (b) the conflict between Ja'far Umar Thalib and Muhammad Assewed and Yazid Jawwaz. Later, these two conflicts significantly impact their networks (As'Ad Said Ali, 2012).

Salafis can be grouped into two, i.e. the pure Salafis that focus on the teachings of aqeedah (Islamic theology) and fiqh (Islamic jurisprudence), and the jihadi Salafis whose movements are similar to the Muslim Brotherhood in Egypt. Lately, the Indonesian people are increasingly accepting the pure Salafis, especially the youth who choose the way of hijra (spiritual emigration). For young people, the Salafi Islam teaches Islam in a clear, black-and-white, and not confusing way. The Salafist followers continue to grow recently, and they are known to have a high fighting spirit. They struggle through various strategies and media, such as educational institutions and social media. Slowly but surely, the teachings and doctrines of the Salafi Islam are being accepted by Indonesian Muslim society.

Hasan's research revealed that Salafi $d a^{\prime}$ wah is built on the principle of upholding the virtues of the Prophet's sunnah, setting a direct example to the community and encouraging the purification of tauheed (monotheism). He also identified four goals of Salafi da'wah: the first is to teach Muslims a true and complete understanding of religion to answer various problems of life. The second is to straighten out the distortions 
of understanding among Muslims from bid'ah (heresy) and kufr (infidel). The third is to revive, socialize, and strengthen the practices that have been taught and carried out by the Prophet. The fourth is to foster brotherhood and unity of Muslims on the basis of loyalty and love for the Prophet's sunnah and hatred for bid'ah and kufr. The process carried out by the Salafi group in spreading Islamic teachings is in accordance with the manhaj of salaf al-shalih, e.g. through education and purification (Hasan, 2006).

For Salafi Muslims, wearing the niqab is one of the teachings of Islam that Muslim women must implement. However, the niqab is not just religious teaching and symbol; yet is an instrument to support their socio-political struggle, i.e. the Islamism movement. Islamism is understood as a visionary movement to build a world civilization based on Islamic religion. Tibi stated that Islamism has six aspects, namely: 1) purification of Islam, 2) formalization of Islamic Sharia, 3) anti-democracy, 4) anti-other religions, 5) antiWestern culture, and 6) the use of violence to achieve goals (Tibi, 2012). The basic concept of Salafi Islam in this study uses the formulation introduced by Bassam Tibi.

The niqab in Salafi Islam is studied in the context of social movements. A social movement is a structured, organized, and sustainable collective movement that aims to challenge the established authority, both institutionally and culturally. However, Snow explained that the state is not the only power or authority that becomes the target of Salafi Islam. Other authorities such as religion, politics, culture, economy, and so on also become the target. Thus, the social movements that are used as the target of Salafi Islam include the various institutions and cultural meanings existing in the society (Benford \& Snow, 2000; Snow, 2004). 
For Snow, the sociopolitical movement opposes what is referred to as institutional authority - both in the political area such as the state and others such as corporations, religion, education, or cultural sources that include belief systems or religious practices. The niqab for Salafi activists is a logical consequence of their religious ideology, that as an Islamic movement, Salafi Islam has strategies in packaging the ideology. In this context, the niqab is one of the instruments of resistance to contemporary phenomena (Kulenović, 2006), while it is also a sign for the activities of the Salafi activists.

Therefore, as Sunesti, et al. (Sunesti, Hasan, \& Azca, 2018) stated, the niqab can be a unique negotiation medium for the Salafi-niqabi young millennials in today's modern world. Through what Macleod calls accommodation and protest at the same time, they find their hijrah experience an identity negotiation. Similarly, through the niqab, Salafi Islam challenges the sociopolitical conditions towards an ideal order. The niqab phenomenon appears at the same time as the return of conservative Islam in Indonesia (Ahmad, Aziz, Afad, Muniroh, \& Qodim, 2021).

\section{Niqab and the Social Construction of Salafi Islam}

Various factors influence the construction of the niqab, and each region has a different term for it, such as burqa, hijab, chador, etc. They construct hijab according to context and locality. In addition, religious understanding also helps shape the conception and ideology behind the niqab.

Among internal Salafi women, there is a view that the niqab is part of religious teachings. It serves as evidence of one's obedience to Allah's teachings; a person who wears a veil means that she has followed the teachings of Islam. "The 
niqab is obligatory for every woman because it is Allah's commandment," said one of the research subjects (Hana, 2019). However, in practice, the concept of the niqab differs from one group to another due to the different social contexts.

Like other concepts, the niqabisalso understood invarious ways according to the context of the formulator. The concept of the niqab is formulated according to the interpretation and understanding of those involved in the formulation and having an interest. Besides, the motivation of each wearer is also different, and, in fact, it has the most decisive role in the use of the niqab (Legate, Weinstein, Sendi, \& Al-Khouja, 2020). In this case, the construction of the niqab is largely determined by the educational setting, economy, ideology, and values adopted by the formulator and the wearer.

According to Uripa wearing the niqab means practicing the Islamic teaching concerned with covering the aurat (Uripa, 2019). Nonetheless, she believes that not everyone gains hidayah from the beginning. Uripa, for example, felt it was too late for her to carry out this teaching (covering the aurat). She wore the niqab only after attending several religious preaching. Uripa was grateful, because after going through a long process, she finally obtained hidayah. Unlike Uripa's perspective, another niqab wearer named Zahida argues that the niqab is a mere garment of Muslim identity. According to her, the niqab is what differs between Muslims and non-Muslims. The niqab is a distinguishing feature between Muslims and non-Muslims (Zahida, 2019). It also distinguishes between Salafi Muslims and non-Salafi Muslims. The results of the observation by the researcher at Majlis Taklim Al-Izzah and its surroundings indicate that the niqab worn by Salafi women is characterized by covering the face and leaving only the eyes, is black in color, covers the whole 
body, and is equipped with socks. These characteristics are quite different from the clothes used by the non-Salafi women and the community surrounding the Majlis Taklim Al-Izzah area in Pekalongan. In this case, non-Salafi women wear only a jilbab (simpler version of veil), not the niqab that covers the whole body (Observation, 2019).

In addition, it also serves as clothing or a medium that may protect the wearers from the temptation of others; the niqab is a protector and safety. Zahidah's claim is certainly different from the results of Shirazi's (2010) research on young Muslim women in Europe and America (Shirazi \& Mishra, 2010). They understand the niqab according to need and function. This is certainly different from Zahidah's understanding, the veil is a cultural identity, social identity and also religious identity. From this point, we know that the niqab is a cultural, social, and religious identity.

Umi, a Salafi activist and owner of a niqab business in Yogyakarta, has a view that the niqab has a broad dimension. There are economic, political, cultural, and religious dimensions. Umi said: "What should be renewed? (The niqab) should not stop at the function of covering the aurat alone, but also on other functions. Muslims should be able to regulate themselves. With the niqab, we organize and fight against traditions concerning the domination of the way of dress, lifestyle, clothing business, and others." (Umi, 2019).

The views from Uripa, Zahida, and Umi illustrate the diversity of opinions and experiences. The niqab becomes a religious, cultural, and political issue at the same time. Another Salafi activist in Yogyakarta named Laras also believes that the niqab is a religious obligation. She argues that the niqab is a cover for aurat and is an Islamic law that must be carried out, wherever and whenever. According to her, Muslims must 
do a dakwah (preaching religious teachings) so that people who do not wear the niqab are given guidance (Laras, 2019).

Similarly, Fatima views that the niqab is a commandment and part of religious teachings that must be carried out to achieve an accurate and perfect Islam (Fatima, 2019). This view is in line with the principles developed by Salafi Islam through the slogans "Back to the Quran and Hadith." Moreover, Salafi Islam also interprets sacred texts literally (Sumbulah, 2009) and proposes the formalization of Islamic sharia (Roy, 2017). In Fatima's view, Islamic teachings cover all aspects of human life. Islam teaches its followers to wear the niqab. The niqab itself covers a woman's head, hair, chest, and even face to prevent unwanted actions (Fatima, 2019). More than that, Umi also considers that the niqab is also related to political affairs and resistance to the domination of established culture, economy, and religion (Umi, 2019).

Meanwhile, in the context of the Salafi movement in Indonesia, the niqab possesses a religious meaning, especially among Muslim women. Wagner et al. (Wagner et al., 2012) compared the construction of the niqab in Muslim majority countries majority to that in the Muslim minority countries. In countries with a large Muslim population, the niqab means comfort, fashion, and modesty. It is also related to religion as the women's reason in wearing the niqab. On the other hand, responses dealing with the niqab in the Muslim minority countries are varied; their motives about the headscarf (niqab) are quite varied, e.g. religion-inspired arguments, convenience reasons, and opposition to stereotypes and discrimination. However, these findings are contrary to the views of the majority of non-Muslim countries in the West. There, the niqab for Muslim women is seen as a symbol of religious fundamentalism and patriarchal oppression. 
From the context mentioned above, Salafi women help construct various meanings of the niqab, religious teachings, as well as Muslim women's identities. They think that wearing the niqab is a form of obedience to Allah; it is a religious obligation for Muslim women to cover their bodies. Women who wear the niqab are considered pious because they have obeyed Allah's order and stayed away from His prohibitions. Further, the niqab also serves as an identity distinguishing one religion from another. It is a Muslim identity though it may have different styles depending on the conditions of the society (Meilinawati, 2016). In this current study, the niqab is interpreted as an instrument of jihad (struggle) against social, economic, cultural, and political injustice. It is a resistance against global capitalism and traditional dressing methods not according to Islamic teachings (Salafi Islam).

\section{On Being Salafi Woman: Process, Experience, and Promotion}

In the context of the Salafi movement in Indonesia, the niqab has an important and strategic position. It is known not only as a garment covering the parts of the body and Islamic teaching, but also a symbol of kaffah Islam, i.e. submission to Islam thoroughly without exception. For Salafi Islam, the niqab represents not only one's piety but also an instrument of da'wah. It is in this context that the niqab is a means of promoting Salafi Islam. For Salafi Muslims, such as Uripa, the process of wearing the niqab is part of religious experience as a Muslim woman. At first, she did not wear the niqab and she had gone through a relatively complicated process before deciding to wear the niqab (Uripa, 2019). 
Uripa's experience shows that each majlis ta'lim has set up a standard in covering the aurat (parts of the body). Likewise, an Islamic community named Majlis Taklim al-Izzah in Kramatsari of Pekalongan also has different rules. The said community insists that the veil, as commonly used by Muslim women in Indonesia, is not shar'i (according to sharia). All of the members of Majlis Taklim al-Izzah wore the niqab. Uripa, who did not wear the niqab at that time, felt that she was not part of the Salafi community yet. Uripa's case informs that the niqab has become a symbol of identity for certain Islamic communities. The niqab becomes a garment differentiating from other groups. The niqab worn by the Salafi community at al-Izzah explains the differences in clothing among Muslim women in general. Mahanani (2016) revealed that Salafi women cover their faces with cadar, a wide veil that hangs down to their knees. They wear a robe that is not tight (loose), not thin, not see-through, not patterned, and dark in color. They do not use perfume or fragrances, nor jewelry, resemble men's clothing, and those similar to the clothes of kafir (infidel) or fasik (wicked) women (Mahanani, 2016).

Indeed, Salafis promote the niqab massively so that women who are not wearing the niqab will immediately wear it. In this context, Salafi activists persuasively approach Muslim women to participate in their Islamic learning class or majlis ta'lim. They persuaded those women to join Salafi community to get to know the true Islam. According to the Salafis, wearing the niqab is the way to perfect one's Islam. Uripa narrated her first experience of wearing the niqab: "I was convinced, invited, and persuaded to wear the niqab, to become a Salafi Muslim woman in accordance with the Sharia. Since then, I have known that the niqab is the garment that Muslim women should wear. ...Now, it's my turn to invite 
and influence others to become Salafis and wear the niqab" (Uripa, 2019).

For Salafi activists, regeneration and expansion of the Salafi Islam doctrines can be carried out through the media of majlis ta'lim. The case that happened to Uripa is a clear example that an Islamic learning class can become a vehicle for Muslim women to dress in accordance with Islamic law. For Uripa, her decision to wear the niqab is a form of guidance for not everyone obtains this kind of gift (guidance) to cover their aurat. However, Uripa admitted that the enlightenment she received was not free. Many sacrifices are required; ups and downs are also unavoidable.

Zahida's involvement in the Salafi community is quite different from Uripa's. Uripa went through the Islamic learning class at Majlis Taklim, whereas Zahida came through a Salafi group leadership training event. The event is intended not only as a means to increasing the capacities and skills of participants in leadership, but also as a medium for recruiting Salafi members. This leadership event is seen as the follow-up (final phase) of the personal approach (Zahida, 2019).

According to Zahida, she wore the niqab due to the neighborhood influences. During the leadership training, she was with the team, most of whom were wearing the niqab. Zahida felt embarrassed that her hijab was still short and small. She then gradually wore a large hijab. According to Zahida, wearing the niqab means protecting her family, parents, husband, and others from the torments of hellfire. Zahida believes that the niqab can save her husband and parents from hell. The niqab becomes a shield from evil, keeps ones away from sinful behavior, and goes against any clothes that still expose the aurat. In training, participants are taught to fully embrace Islam and make the Qur'an a guide for life, i.e. 
ibadah (worship), muamalah (transaction), social, political, and economic life. Through this indoctrination, Zahida finally decided to wear the niqab. "My motivation to wear the niqab is because I love my parents and husband. I don't want to see them go to hell because I don't dress according to Islamic teaching," said Zahida.

Atfirst,Zahidafeltawkwardanduncomfortableinwearing the niqab. Wearing the niqab amid people who did not wear a face-covering may cause suspicion, prejudice, and discomfort. During that time, Zahida began to adjust to the environment. She told: "I once felt uncomfortable or embarrassed because maybe at that time the niqab had not internalized in me and in my heart. Now it is different. I feel okay when in an environment where not everyone wears the niqab. We are simply obliged to convey the truth." (Zahida, 2019).

The style and the way to cover aurat is a conscious choice of each person. Everyone has different tendencies and preferences. For Zahida, one should not interfere with other people's clothes. For her, other people's clothing issue is not our responsibility, it is the responsibility of each person instead. Zahida stated, "I will still wear my niqab, and you must not stop me or ask me to take it off." (Zahida, 2019).

For Zahida, the decision to wear the niqab was a long and challenging road. It is not an instant decision as it takes a long process of self-dialogue and reflection. Wearing the niqab is also a process of being mature in religion. It is an effective tool to promote Islamic identity to other parties (Aryanti, 2015). Zahida maintains that the niqab is an effective $d a^{\prime} w a h$ medium. Another Salafi woman named Hana informed, "I was invited by my friend to participate in an Islamic class at a mosque in the Kraton area, Pekalongan. Masya Allah, I am amazed by the way the sisters dress. They wear large hijab 
and dark clothes with the niqab. I feel peace to look at them. Since then, I have started to routinely take part in their studies though sometimes my mood changes. Now, I am already istiqamah (in wearing the niqab)."(Hana, 2019).

The experiences revealed by Uripa, Zahida, and Hana confirm that the niqab is not a mere Islamic teaching or Muslim women's identity. It is also a means of preaching and spreading the values, teachings, and doctrines of Salafi Islam. Using Benner's language, Islamization can be done through clothing (Brenner, 1996). The niqab for Salafi women is an effective medium of salafization and promotion of Salafi Islam doctrines.

\section{E. Niqab and the Resistance of Salafi Women}

This current study reveals that the niqab also serves as an instrument of resistance against individuals or groups who negatively view Salafi women, the hegemony of global capitalism, traditional values in dressing, and Indonesian society's attitude dealing with covering aurat. Such a fact is specifically different from the research findings proposed by researchers (Jailani, 2016; Jardim \& Vorster, 2003; Mernissi, 1999; Nasir, 2004; Shirazi \& Mishra, 2010; Wagner et al., 2012).

\section{Resistance to Prejudice and Stereotypes}

Women who wear the niqab often become the center of attention. However, the public response to them is quite diverse. Although many people show positive reactions toward the niqab, some still look at the niqab negatively and marginalize those who wear it (Ratri, 2011). The bad image of women wearing the niqab is getting stronger, especially when news about 
terrorism and violence in the name of religion appears in the media. Alexandra Gouveia (Gouveia, 2020) reported that 10 countries had prohibited the niqab, following the news about radicalism, fundamentalism, and terrorism. Uripa's case in this current study proves this fact. She once said, "People who have just met me or have just seen me will usually keep distance from me. Nevertheless, I have always tried to mingle with them by greeting them to know that I am not a dangerous person (Uripa, 2019).

The same fact happened to Zahida. Many people seem to be afraid of the niqab and see it as a strange garment. "At first, maybe people think that the niqab I am wearing is strange and scary. They often suggest that I take off the niqab," Zahida explained. For Zahida, the bad image given to Salafi women is understandable because, according to her, people do not know and understand the true teachings of Islam. She continues to interact, mingle, and invites people to cover their aurat. According to Zahida, the clothes worn by Salafi women did not violate the law. Therefore, those who do not wear the niqab should be given the proper understanding; they need to be embraced. If (this step) still does not work, we will fight with good arguments and actions (Zahida, 2019). Salafi women also face various prejudices, attacks, and accusations. They are considered inclusive, extremist, and anti-social.

In general, there is no significant difference in how the communities in Pekalongan and Yogyakarta treat women covering their faces. Salafi women are 
often suspected, marginalized, and viewed cynically by the surrounding community because of different ways of dressing. A Salafi woman named Hana said, "In urban areas, the pressure (of wearing the niqab) is not too strong because people there are educated. However, it is still considered a strange thing in this village, and people are not open-minded enough (Hana, 2019). Hana's explanation shows that the community has not accepted the niqab as Muslim women's clothing. The niqabis (a label addressed to those wearing the niqab) are excluded because of their different ways of dressing. They are seen as dangerous and suspicious, mainly when riots and violence occur (Hancock \& Mobillion, 2019). Therefore, in certain countries, the niqab is prohibited in public places. The niqabis are often suspected and removed from social and political life (Jailani, 2016).

According to Salafi women, negative views and judgments of women in niqab need to be corrected so they would not become fitnah (hoax). Uripa (2019) recounted: "I received bad words. I was said to be mad or cold, just because of wearing niqab, socks, and gloves all day long. (But) I'm sure (that this misunderstanding is) because they don't know yet. I believe that covering aurat is an obligation, and I do my best." (Uripa, 2019).

The majority of those who wear the niqab had negative experiences. From observations in the area around the Majlis Taklim, where the niqabis do their activities, the researcher found the bad treatment experienced by women in niqab, such as satire, negative comments, and even bullying, when they crossed the 
road to the mushalla. (Observation, 2019). According to Uripa, one of the Salafi activists, “... in the face of insults, I and my ahwat remained patient and adhered to the principle that the niqab is religious teaching. The duty as a Muslim is to preach, convey prophetic messages. The niqab is an obligation." However, in non-Middle Eastern countries, such as Indonesia and Europe, wearing the niqab is full of challenges and challenges (Jailani, 2016). The challenge of using the niqab has been experienced by Zahida, that she was ostracized and insulted by her friends (Zahida, 2019).

The experience of wearing the niqab is unique. The researcher observed that when the niqabis walked to AlIzzah Mosque for Maghrib Prayer, the people along the way looked at them cynically, the neighbors whispered about them, and the children ridiculed or bullied them (Observation, 2019). Aini, one of the niqabis, revealed her experience of wearing the niqab. According to her, many people are cynical and have a negative opinion and even consider her part of a terrorist network or a cult (Aini, 2019). There are different experiences among Indonesian, European, and American Muslim women in wearing the niqab. Each place or geography brings a different context. There are historical, social, political, and cultural considerations that must be considered in understanding and studying the niqab phenomenon. A study conducted by Shirazi \& Mishra (2010) on Muslim women wearing the niqab in Europe shows that academic literature and media reports on young Muslim women in Europe indicate that wearing the niqab is often 
viewed as an act of rebellion (Shirazi \& Mishra, 2010). Meanwhile, in America, wearing the niqab is a form of personal, political, cultural, and religious identity. However, the presence of the niqab in the public domain remains a contentious issue (Moore, 2007).

The negative response given by the community did not make the spirit of these Salafi women down. On the contrary, this situation has strengthened their belief to remain committed to promoting the niqab. In the Indonesian context, the struggle against gender stereotypes and discrimination, including wearing the niqab, is getting more support as a new generation of feminist men are born in fighting for social justice (Ahmad, Muniroh, \& Mahmudah, 2021). They view this situation as a test and a challenge that requires patience. Hana said, "The niqab that I wear is not common in the local community and will inevitably lead to accusations of vileness or fitnah. Our task is to correct and resist the accusations by remaining in the niqab and behaving well and politely" (Hana, 2019). It means that the trend of wearing the niqab by Salafi women is to fight and clarify the negative stigma of Muslim women wearing niqab (Kusmiati, 2020). Thus, on one hand, the niqab becomes a reason for someone to be suspected and judged badly, but on the other hand, it becomes the strength to fight against these negative stigmas and stereotypes.

\section{Resistance to Capitalism and Global Markets}

Salafi Islam in Indonesia has developed the commercial business through various channels. Niqab 
is one of the promising lines of business and market for the Salafi community. However, the development of the Salafism movement is more influenced and supported financially by donor agencies from the Middle East, especially Saudi Arabia (Jahroni, 2020). For the Salafi community, the niqab cannot be separated from the religious $d a^{\prime} w a h$, a response to global political developments, and business aspects simultaneously. A Salafi activist named Umi illustrates, "The niqab business is a way of spreading Islam. We always preach Salafi teachings, one of which is by wearing and trading this niqab. There are other ways too, such as Islamic discussions, halaqah, and commercial business of Salafi products. The profits from the sale of our products are used for the benefit of $d a^{\prime} w a h$ and the welfare of our workers." (Umi, 2019).

The explanation of the Jubahakhwat's owner above indicates that the niqab business network is not intended only for material gain. Umi, who is also an activist at Pondok Pesantren SJR Al-Salafy of Yogyakarta, integrates trade, worship, and social concerns. The niqab business with a religious spirit is certainly different from business activity in general, which is only profit-oriented. The niqab is a major project in the concept of hijrah in the view of the Salafi Islam followers, such as Umi, Uripa, Zahida, and Hana. For Muslim women, the niqab is a symbol of hijrah, which signifies a transformation to leave incorrect behaviors towards the Divine path of Islam, i.e. kaffah Islam. In the context of salafization, the niqab has become an essential instrument in da'wah, 
promotion, and branding strategies that can be done through religious forums, trade, or social media.

For Hana, wearing the niqab has a dual function. Firstly, the niqab means a strategy to influence others to follow in her footsteps as well as a resistance to dressing and the business model of capitalism. Secondly, the niqab is an expression of iman (faith), and it is the core business of Salafi Islam (Hana, 2019). The niqab is increasingly in demand, as the spread of $d a^{\prime}$ wah through social media has increased sharply, along with the rise of advertising for products or services with Islamic nuances in the last 10 years.

However, Hana and Umi do not deny fierce competition in seizing the market and consumers. Hana said, "Now there are many models of covering the aurat, but they are not in accordance with the sharia. Only the niqab model is sharia-compliant. In fact, the niqab seems to have become a fashion business and has become the center of attention of business people. But whatever the circumstances, this niqab should be promoted to Muslim women because it is following Islamic doctrine." (Hana, 2019). The Salafi business network community realizes the need for competition so that the niqab business is able to compete to win the consumers. Umi does not only deal with the owners of capital but also has to influence buyers to be interested in the niqab as a Muslim daily dress. Next, in the face of liberal market competition, Umi puts more importance on quality and tries to use religious approach, i.e. the consumers' faith. 
For Umi, the niqab business competes not only with fellow niqab sellers but also with the non-sharia clothing business (Umi, 2019). In this context, the niqab has become part of the industry and the market. Since 2015, niqab exhibitions have been frequently held, such as in Indonesia Fashion Week, Jakarta Fashion Week, Niqab Squad, up to an event named Hijrah Indonesia Millenial Summit 2020. In fact, the niqab business in Indonesia is constantly increasing from year to year. Now, wearing the niqab has become a necessity, not only for Salafi women, but also non-Salafis. Zahida, a Salafi Niqabis at Pondok Pesantren SJR Al-Salafy of Yogyakarta, feels that something is missing when she is not wearing the niqab (Zahida, 2019). Although Wagner et al. (Wagner et al., 2012) have reported that the niqab wearers in Indonesia are mostly following fashion or comfort, the fact that the niqab business has religious, network, financial, and market dimensions cannot be denied.

According to Umi, the Salafi-niqabi business is not only profit-oriented, but also has dimensions of religion, da'wah, networking, and community welfare (Umi, 2019). This fact is different from what is developed by the capitalist business that mainly focuses on financial gain, profit orientation, and partiality to investors. The niqab business networks, both national and transnational, have further strengthened the Islamic Salafi movement in Indonesia (Slama, 2011). For example, halal cosmetic products and sharia hotels currently growing are getting the right momentum with niqab clothing. These products and hotels often involve figures in Islamic 
clothing in their advertisements, i.e. women wearing the niqab with the whole body covered. The Salafist niqab business is an alternative source of funding for da'wah and the welfare of the Salafi community.

\section{Resistance to Tradition and Secularism}

For Salafi women, wearing the niqab means both practicing religious teaching and forming world civilization. There is political contestation in seizing the influence at the local level and at the global level. The niqab clothing is meant to criticize the non-syar'i clothing at the local level, as recounted by Zahida (2019). Meanwhile, at the global level, it is a resistance to modernity and secularism. Given this context, the women experience social contestations and social dilemmas (Vidyasagar \& Rea, 2004). Within the Islamic movement, the niqab is a vital force to block moderate Islamic movements that are inclusive and adaptive to outside cultures. Further, this contestation will ultimately affect the face of Islam at the global level (Rabasa, 2004).

Researchers have been in agreement that the niqab is inseparable from the Salafi da'wah movement in Indonesia. At the initial level, the use of the niqab was associated with the decline of Muslims. For Salafi Muslims, today's Muslims are experiencing a setback compared to the era of the Prophet, companions, and Salaf generations. A study conducted by Hidayat maintained that Islam is currently in a difficult situation (Hidayat, 2014). According to his study, some parties 
are allied to degrade, want to dominate, and weaken Islam's power. Salafi activists believe that non-Muslim groups are now trying to colonize Muslim territory. They eat, steal, and reap the wealth of Muslims greedily, while none is able to prevent them (Hidayat, 2014). According to them, the kafir groups are no longer afraid of Muslims because they have lost their power and dignity. They are now infected with al-wahn disease (Jawas, 2008), the disease that appears as the Muslims have been far from the Quran and Sunnah and do not follow the path of the sahabat (Prophet's companions).

In the Salafis' view, covering the parts of body without the niqab is evidence of incorrect understanding of the Prophet's teachings and the sahabat's behavior. Muslim women who do not wear the niqab, therefore, have not followed the Islamic teachings properly. This fact is actually what may cause Islam stepping back; Islamic civilization suffers a setback because Muslims abandoned the teachings of their religion.

Salafi Islam is present to answer the Muslim condition with the spirit of purifying the teachings of monotheism and following the Sunnah of the Prophet in various aspects of life, including the niqab for women. Hasan's (2006) research reveals the main characteristics of the Salafi group: they wear jalabiyah (long robes), imamah (turban), isbal (pants with its length is only up to the ankles), and lihyah (long beard). Meanwhile, Salafi women wear the niqab (face cover). In this sense, Salafism comes to respond to two things at once, i.e. the internal situation of Muslims and the 
external conditions of Muslims (such as secularism and modernism). Therefore, the development of the Salafism movement went hand in hand with the emergence of Islamic politics to face Western colonialism and the obsession with rebuilding the Ummah through the Islamic caliphate (Hourani, 1983).

For Salafi Islam, the glory of Islam will come back if Muslims follow the correct understanding of Islam and uphold the Islamic laws. According to Hidayat's (2012) research, Salafi Islam has formulated a solution concerning the underdevelopment of Muslims, namely returning to the Qur'an and Sunnah that are in line with the teachings of the Prophet, companions and Salaf alShalih (the pious Predecessors). These ideals begin with upholding the tawheed (monotheism) and getting rid of shirk (Jawas, 2008). For the Salafi group, wearing the veil is a clear evidence of returning to the Qur'an and Sunnah.

To understand Islam in the contemporary context, in practice, people should focus on both the aspect of worship and all aspects of life. This principle applies to both men and women. Special for women, they are required to cover their aurat tightly. Lara stated: "We also wear the niqab to fight against the traditions of improper dress, namely open clothes or the ones that expose the aurat, and secular clothes." (Laras, 2019).

In the Salafi activists' view, as expressed by Laras above, the niqab is one solution to overcome the backwardness of Muslims today. At this stage, the Salafi movement serves as an effort to find solutions to the problems faced by women. According to Laras, when 
women don't wear the niqab, men who are not mahram (strange men) will see our aurat. Islam forbids seeing other people's aurat. Strange men are allowed to see a woman's face only to propose and marry her. Apart from those purposes, (looking at her face) is not allowed and is considered a sin. Many claim to be a Muslim woman but their aurat is still visible. They even wear only t-shirts and shorts. By wearing the niqab, we are fighting against secular people's dress code and improper dress traditions (Laras, 2019). Laras' experience confirms that the niqab has a spirit of resistance to women's dress traditions and men's habits. At this stage, Salafi women are actively involved in improving the situation through the collective action of wearing the niqab. Fatima stated "As Muslim women, should always carry out Islamic teaching and do $d a^{\prime}$ wah so that someday we will become angels of heaven" (Fatima, 2019).

In the context of the resistance movement, the da'wah carried out by the Salafi niqabis is to invite Muslim women to wear the niqab and cover their aurat, and to fight against the dominance of secular lifestyles and clothing. This means that Salafi women are a subculture that creates its own cultural expressions while at the same time developing uniqueness that can violate the dominant tradition. They fight against the established way of dressing and create a distinction among popular culture, namely covering the aurat that other people generally wear (Mahanani, 2016). This stage is a ladder towards the achievement of the movement's ideals. The Salafi niqabi activities are a solution to the practices that 
are not in accordance with sharia. They struggle to uphold Islamic teachings through religious studies, halaqah, book publishing, and the establishment of pesantren, radio stations, and social media. In their religious gatherings, the narrative of heaven and hell always appears as a reward and punishment for human actions. Heaven becomes a commodity in every religious gathering, halaqah, meeting, and Islamic books they publish.

The phenomenon of the niqabi women also confirms the Ghoshal's findings stating that Islam in Asia, especially Indonesia, for centuries has been known for its ability to adapt to local practices and be tolerant of other cultures and religions. Over the past three decades, fundamentalists, jihadists, and Salafists have aggressively presented Islamic symbols, including the niqab. However, in the context of the niqab, Salafi Islam in Yogyakarta and Pekalongan do not adapt to local culture. Instead, they try to dominate and promote a truth claim that the niqab is the most sharia-compliant women's clothing.

In reality, the niqab phenomenon has brought tension, sparked the conflict, and divided Muslims. The massive campaign that those not wearing the niqab are considered non-compliant Muslim women has triggered various religious disputes. In this context, Salafi groups have used the niqab as a medium of protest and resistance against the syncretic and inclusive practice of local Islamic dress. The niqab as a representation of Islam in the desert has spread to remote parts of Indonesia through the influence of 
ideas, norms, practices, and donations flowing from the Arab world (Jahroni, 2020). The niqab has become a tool for the homogenization and regimentation process, which Ghoshal calls the Arabization of Islam (Ghoshal, 2010). This Arabization of Islam emphasizes identity, symbols, rituals, and codes of ethics rather than spiritual substance. Through the Salafi doctrines, the niqab and $d a^{\prime} w a h$ organizations have transformed into an effective and broadly influential political force in Indonesia (Muhsin, Rochmawati, \& Huda, 2019). Here, the internationalization of Salafi Islam through the niqab becomes an easy way for Salafi activists to gain economic or political advantage (Ghoshal, 2010).

Religion-based business through the niqab also makes religious gatherings and studies conducted by Salafi activists a strategic way to achieve targets. They always insert the narration of tawheed (monotheism) and religious understanding in accordance with the Prophet's companions in every activity as a spirit to expand the influence of Salafi Islam. Such a narration becomes a mantra to achieve success and safety in this world and the hereafter. The niqab does have an influential political power (Wallach Scott, 2007). The niqab movement is a form of resistance to religious ways that are not kaffah towards Islam in totality. Women wearing the niqab have been participating in restoring the Islamic teachings according to the prophet's doctrines.

At this point, the promises of heaven, behind the discourse of the niqab, are raised. Fatima explained: "Whoever upholds Islamic law will get the heaven. 
Wearing the niqab is a form of enforcing Islamic law. The niqab is a medium of struggle to compete and fight against ways of dressing that expose the aurat and a nonsyar'i lifestyle." (Fatima, 2019). Statement of the Salafi niqabis shows a correlation between the niqab with religious orientation and the struggle to implement the khilafah system in Indonesia. The movement style is also varied from educational to political aspects (Mustofa, Enizar, Hadi, \& Irwansyah, 2019). The results of a study conducted by Dzuhayatin strengthen this finding. That is, more than $50 \%$ of women who wear the niqab support the khilafah system. According to him, one of four niqabis considers that the system implemented by the Indonesian government now is taghut (non-Islamic) (Dzuhayatin, 2020).

Moreover, $15 \%$ agree to defend Islam by using violence (Dzuhayatin, 2020). Such facts are alarming for the Indonesian nation, which is multi-racial, ethnic, cultural and religious. However, negative judgments and unfair treatment of Salafi Niqabi should not be carried out by anyone, be it individuals, groups, or countries. In order to regain rights and justice, both in the understanding of Islam and in the context of nationality, women must also be actively involved in interpreting the texts and laws (Othman, 2006). Any involvement in upholding rights and expression must consider the fact that Indonesia's nation-state is multicultural (Ahmad, 2021; Pratama, 2021; Selvia \& Sunarso, 2019).

In short, we come to know that, as an essential instrument, the niqab is, in fact, a tool and medium of 
da'wah that cannot be underestimated. The increasing interest in the use of the niqab in Indonesia affects the success of Salafi Islamic da'wah. There is a contribution of the niqab as a symbol in expanding the influence of Salafi Islam. The niqab, on the one hand, is an identity to reflect behavior and dress code that are in accordance with the sharia and, on the other hand, is a tool of propaganda, of protest, of $d a^{\prime} w a h$, and of salafization to influence Indonesian Muslim women to become the Salafi Islam followers.

\section{F. Conclusion}

Previous studies that see the niqab as a means of patriarchal control against women; as a religious identity, a symbol of the marginalization and inferiority of women; as a picture of troubled, isolated, and excluded women; and as a choice in the name of comfort, fashion, and modesty following religious reasoning are not always appropriate to describe the phenomenon of Salafi Muslim women in Pekalongan and Yogyakarta. Unlike those studies, this current study maintains that the niqab for Salafi Muslim women is a media of $d a^{\prime}$ wah and campaign to expand the influence of Salafi Islam. It also serves as an instrument of propaganda instrument and a symbol of protest and resistance to religious traditions, secularism, and global capitalism.

Although Salafi women have relatively the same religious style, they interpret the niqab differently. The plurality of views about the niqab is caused by the diversity of subjects with different interests and backgrounds. These various views revolve around: the niqab is an Islamic law, one of the Prophet's teachings, a cultural product, and in accordance 
with the fashion development model. However, this diversity of views on the niqab is bound by one mission that the niqab is an instrument of $d a^{\prime}$ wah to expand the influence of Salafi doctrines amid Muslim society.

The thesis of this study shows that the niqab brings the spirit of protest against the established traditional Islamic order. It is also a form of resistance to the views and behaviors of the majority religion, resistance to negative stigma, and resistance to the pop clothing business. The results of this study seem to go beyond Tarik Kulenovi's study stating that the niqab is a form of resistance to the mainstream of modernity. This study has confirmed that the niqab is an important symbol and instrument of the social resistance movement against local traditions, clothing business, global capitalism, and traditional people's religiosity established in Indonesia.

\section{REFERENCES}

Ahmad, M. (2021). Indonesian Muslim Youth and the Discourse on the Caliphate System, Islamic State and Sharia-Based Regional Regulations. RELIGIA, 24(1), 79-99. https:// doi.org/https://doi.org/10.28918/religia.v24i1.4191

Ahmad, M., Aziz, A., Afad, M. N., Muniroh, S. M., \& Qodim, H. (2021). The Sufi order against religious radicalism in Indonesia. HTS Teologiese Studies/Theological Studies, 77(4), 1-11. https://doi.org/https://doi.org/10.4102/ hts.v77i4.6417

Ahmad, M., Muniroh, S. M., \& Mahmudah, U. (2021). Male Feminists Promote Gender Equality in Islamic Moderation Perspective. Religious: Jurnal Studi AgamaAgama Dan Lintas Budaya, 5(2), 175-186. https://doi. 
org/https://doi.org/10.15575/rjsalb.v5i2.11436

Aini. (2019). Salafi-Niqabis. Personal communication.

Aryanti, T. (2015). Branding the Islamic Village: Modesty and Identity in Yogyakarta Kauman Village, Indonesia. Procedia-Social and Behavioral Sciences, 184, 126-134. https://doi.org/10.1016/j.sbspro.2015.05.070.

As'Ad Said Ali, I. G. (2012). Pasca-Reformasi: Gerakan Sosial Politik Dalam Tinjauan Ideologis. Jakarta: LP3ES.

Benford, R. D., \& Snow, D. A. (2000). Framing processes and social movements: An overview and assessment. Annual Review of Sociology, 26(1), 611-639. https://doi. org/10.1146/annurev.soc.26.1.611

Brenner, S. (1996). Reconstructing self and society: Javanese Muslim women and "the veil." American Ethnologist, 23(4), 673-697. https://doi.org/10.1525/ ae.1996.23.4.02a00010

Chozin, M. A. (2013). Strategi Dakwah Salafi di Indonesia. Jurnal Dakwah, 14(1), 1-25. https://doi.org/https:// doi.org/10.14421/jd.2013.14101

Cohen-Almagor, R. (2021). Indivisibilité, Sécurité, Laïcité: the French ban on the burqa and the niqab. French Politics, 1-22. https://doi.org/https://doi.org/10.1057/ s41253-021-00164-8

Dzuhayatin, S. R. (2020). Islamism and nationalism among niqabis women in Egypt and Indonesia. Indonesian Journal of Islam and Muslim Societies, 10(1), 49-77. https://doi.org/10.18326/ijims.v10i1. 49-77

Fatima. (2019). Salafi-niqobis. Personal communication.

Ghoshal, B. (2010). Arabization: the changing face of Islam 
in Asia. India Quarterly, 66(1), 69-89. https://doi.org/ https://doi.org/10.1177\%2F097492841006600105

Gouveia, A. (2020). 10 Countries Where Women Are Forbidden To Wear The Veil. Juli, 2020. Lembaga Penelitian, Pendidikan, dan Penerangan Ekonomi dan Sosial.

Hana. (2019). Salafi-Niqabis. Personal communication.

Hancock, C., \& Mobillion, V. (2019). "I want to tell them, I'm just wearing a veil, not carrying a gun!" Muslim women negotiating borders in femonationalist Paris. Political Geography, 69, 1-9. https://doi.org/https://dx.doi. org/10.1016/j.polgeo.2018.11.007

Haryanto, S. (2015). Sosiologi Agama: Dari Klasik Hingga Postmodern. Ar-Ruzz Media.

Hasan, N. (2006). Laskar Jihad: Islam, militancy, and the quest for identity in post-New Order Indonesia. SEAP Publications.

Hidayat, D. (2014). Gerakan Dakwah Salafi di Indonesia pada Era Reformasi. MASYARAKAT: Jurnal Sosiologi, 17(2), 115-133. https://doi.org/https://doi.org/10.7454/ mjs.v17i2.3738

Hochel, S. (2013). To Veil or Not to Veil: Voices of Malaysian Muslim Women. Intercultural Communication Studies, 22(2), 40-57.

Hourani, A. (1983). Arabic thought in the liberal age 17981939. Cambridge University Press.

Jahroni, J. (2020). Saudi arabia charity and the institutionalization of Indonesian Salafism. Al-Jami'ah: Journal of Islamic Studies, 58(1), 35-62. https://doi.org/ https://doi.org/10.14421/ajis.2020.581.35-62

Jailani, Y. (2016). The struggle of the veiled woman:'white 
savior complex'and rising islamophobia create a twofold plight. Harvard International Review, 37(2), 51-54.

Jardim, G. L., \& Vorster, J. M. (2003). Hijab and the construction of female religious identity. In Die Skriflig, 37(2), 271287. https://doi.org/https://hdl.handle.net/10520/ EJC107986

Jawas, Y. bin A. Q. (2008). 2010. Mulia Dengan Manhaj Salaf, Bogor: Pustaka At-Taqwa.

Karim, S. (2016). Islamism: Expression of Political Islam and Islamic Politics in South Sulawesi. JICSA (Journal of Islamic Civilization in Southeast Asia), 5(2), 122-135.

Kulenović, T. (2006). A veil (hijab) as a public symbol of a Muslim woman modern identity. Collegium Antropologicum, 30(4), 713-718. https://doi.org/ Original scientific paper

Kusmiati, Y. (2020). Pengungkapan Diri Muslimah Bercadar melalui Instagram: Pendekatan Fenomenologi. https:// doi.org/https://repository.uinjkt.ac.id/dspace/ handle/123456789/54327

Laras. (2019). Salafi-Niqobis. Personal communication.

Legate, N., Weinstein, N., Sendi, K., \& Al-Khouja, M. (2020). Motives behind the veil: Women's affective experiences wearing a veil depend on their reasons for wearing one. Journal of Research in Personality, 87, 103969. https:// doi.org/https://doi.org/10.1016/j.jrp.2020.103969.

Mahanani, P. A. R. (2016). Perempuan Salafi Memaknai Jilbab: Antara Alternatif dan Oposisional. Sospol: Jurnal Sosial Politik, 2(1), 123-136. https://doi.org/http://dx.doi. org/10.22219/sospol.v2i1.4760.

McLarney, E. (2009). The burqa in vogue: Fashioning Afghanistan. Journal of Middle East Women's Studies, 
5(1), 1-23. https://doi.org/https://doi.org/10.2979/ MEW.2009.5.1.1

Meilinawati, L. (2016). Jilbab: Budaya POP dan identitas muslim di Indonesia. IBDA: Jurnal Kajian Islam Dan Budaya, 14(1), 139-155.

Mernissi, F. (1999). The veil and the male elite: A feminist interpretation of women's rights in Islam. Perseus Books.

Moore, K. M. (2007). Visible through the veil: The regulation of Islam in American law. Sociology of Religion, 68(3), 237-251. https://doi.org/https://doi.org/10.1093/ socrel/68.3.237

Moustakas, C. (1994). Phenomenological research methods. Sage publications.

Muhsin, I., Rochmawati, N., \& Huda, M. C. (2019). Revolution of Islamic Proselytizing Organization: From Islamism to Moderate. QIJIS (Qudus International Journal of Islamic Studies), 7(1), 45-70. https://doi.org/http://dx.doi. org/10.21043/qijis.v7i1.5076

Mustofa, I., Enizar, E., Hadi, M., \& Irwansyah, D. (2019). Reading Types of Islamic Fundamentalism in Lampung Province (A Study on Doctrine and Movement of Islamism at Lampung University). QIJIS (Qudus International Journal of Islamic Studies), 7(2), 267-300. https://doi.org/ http://dx.doi.org/10.21043/qijis.v7i2.5719

Nasir, M. A. (2004). The Veil at the Crossroads: Muhammad Sa'îd al-'Ashmāwī and The Discourse on the Hijāb in Egypt. Al-Jami'ah: Journal of Islamic Studies, 42(1), 89-131. https://doi.org/https://doi.org/10.14421/ ajis.2004.421.89-131

Othman, N. (2006). Muslim women and the challenge of Islamic fundamentalism/extremism: An overview 
of Southeast Asian Muslim women's struggle for human rights and gender equality. Women's Studies International Forum, 29(4), 339-353. https://doi.org/ https://doi.org/10.1016/j.wsif.2006.05.008

Pirol, A., \& Aswan, A. (2021). Niqab in Indonesia: Identity and Nationalism of the Female Students in Palopo. Religious: Jurnal Studi Agama-Agama Dan Lintas Budaya, 5(2), 123-134. https://doi.org/https://doi.org/10.15575/ rjsalb.v5i2.10097

Pratama, E. G. (2021). Religion and Public Diplomacy: The Role of Nahdlatul Ulama (NU) in Indonesia-Afghanistan Peace Agenda. Jurnal Penelitian, 18(1), 1-12. https:// doi.org/10.28918/jupe.v18i1.3470

Rabasa, A. M. (2004). Southeast Asia: moderate tradition and radical challenge. The Muslim World after 9, 11, 367412. https://doi.org/www.jstor.org/stable/10.7249/ mg246af.18

Rahman, A. F., \& Syafiq, M. (2017). Motivasi, stigma dan coping stigma pada perempuan bercadar. Jurnal Psikologi Teori Dan Terapan, 7(2), 103-115. https://doi.org/https:// doi.org/10.26740/jptt.v7n2.p103-115

Ramadhini, E. (2017). Jilbab sebagai representasi simbolik mahasiswi Muslim di Universitas Indonesia. MASYARAKAT: Jurnal Sosiologi, 22(1), 81-103. https:// doi.org/https://doi.org/10.7454/mjs.v22i1.6835

Ratri, L. (2011). Cadar, media, dan identitas perempuan muslim. Forum, 39(2), 29-37. Faculty of Social and Political Sciences Diponegoro University.

Razack, S. H. (2018). A site/sight we cannot bear: The racial/ spatial politics of banning the muslim woman's Niqab. Canadian Journal of Women and the Law, 30(1), 169-189. https://doi.org/https://doi.org/10.3138/cjwl.30.1.169 
Roy, O. (2017). Globalized Islam: the search for a new Ummah. Islamology, 7(1), 11-40. https://doi.org/http://dx.doi. org/10.24848/islmlg.07.1.01

Saputra, S., Tanjung, Y., \& Augus, E. (2021). Identity Politics of Veiled Women in Indonesia (Case Study on Niqab Squad Community). Review of International Geographical Education Online, 11(5), 2455-2466. https://doi. org/10.48047/rigeo.11.05.145

Scheid, T. L., \& Wright, E. R. (2017). A handbook for the study of mental health: Social contexts, theories, and systems. Cambridge University Press.

Selvia, L., \& Sunarso, S. (2019). Islamic Boarding Schools in Indonesia: Caring for Nationalism and Preventing Radicalism.JURNAL PENELITIAN, 16(1), 53-64. https:// doi.org/10.28918/jupe.v16i1.1822

Shirazi, F., \& Mishra, S. (2010). Young Muslim women on the face veil (niqab) A tool of resistance in Europe but rejected in the United States. International Journal of Cultural Studies, 13(1), 43-62. https://doi.org/https:// doi.org/10.1177\%2F1367877909348538

Slama, M. (2011). Translocal networks and globalisation within Indonesia: exploring the Hadhrami diaspora from the archipelago's north-east. Asian Journal of Social Science, 39(2), 238-257. https://doi.org/https:// doi.org/10.1163/156853111X565904

Snow, D. A. (2004). Framing processes, ideology, and discursive fields. The Blackwell Companion to Social Movements, 1, 380-412.

Sumbulah, U. (2009). Konfigurasi Fundamentalisme Islam. UIN-Maliki Press.

Sunesti, Y., Hasan, N., \& Azca, M. N. (2018). Young Salafi-niqabi 
and hijrah: agency and identity negotiation. Indonesian Journal of Islam and Muslim Societies, 8(2), 173-198. https://doi.org/https://doi.org/10.18326/ijims. v8i2.173-198

Syed, I. U. (2021). Hijab, niqab, and the religious symbol debates: Consequences for health and human rights. The International Journal of Human Rights, 25(9), 14201435. https://doi.org/https://doi.org/10.1080/13642 987.2020.1826451

Tibi, B. (2012). Islamism and Islam. Yale University Press.

Umi. (2019). Salafi-Niqabis. Personal communication.

Uripa. (2019). Salafi-Niqabis. Personal Communication.

Vidyasagar, G., \& Rea, D. M. (2004). Saudi women doctors: gender and careers within Wahhabic Islam and a 'westernised'work culture. Women's Studies International Forum, 27(3), 261-280. https://doi.org/ https://doi.org/10.1016/j.wsif.2004.06.008

Wagner, W., Sen, R., Permanadeli, R., \& Howarth, C. S. (2012). The veil and Muslim women's identity: Cultural pressures and resistance to stereotyping. Culture \& Psychology, 18(4), 521-541. https://doi.org/https:// doi.org/10.1177\%2F1354067X12456713

Wallach Scott, J. (2007). The politics of the veil. Princeton and Oxford: Princeton University.

Zahida. (2019). Salafi-Niqabis. Personal communication.

Zempi, I. (2019). Veiled Muslim women's views on law banning the wearing of the niqab (face veil) in public. Ethnic and Racial Studies, 42(15), 2585-2602. https:// doi.org/https://doi.org/10.1080/01419870.2019.158 8985 